\title{
Attitude of Postgraduate medical student's towards rural health service in Andhra Pradesh
}

\author{
Dr Ch. Sridhar ${ }^{1}$, Dr P. Radhakumari ${ }^{2}$, Dr S. Appalanaidu ${ }^{3}$ \\ ${ }^{I}$ (PG student, Department of Community Medicine, Andhra Medical Collage, Visakhapatnam, India) \\ 2 (Associate professor, Department of Community Medicine, Andhra Medical Collage, Visakhapatnam, India) \\ ${ }^{3}$ (Professor\& HOD, Department of Community Medicine, Andhra Medical Collage, Visakhapatnam, India)
}

\begin{abstract}
Background: In India $30 \%$ of doctors working in rural areas where $68.84 \%$ of the population is residing. India may not achieve health related millennium development goals, as required investments yet to be made in health sector, although a beginning has been made by the NRHM, which is facing several constraints, notable among these constraints is the insufficient deployment of human resources, especially doctors in the health institutions located in the rural areas.
\end{abstract}

objectives:

1) To know the socio-demographic profile of study population

2) To study the attitudes towards rural health service in study population

Methods: A Cross sectional study was conducted among 100 randomly selected postgraduate medical students of Andhra Medical College, Visakhapatnam with self-administered pretested questionnaire\& Informed consent was taken from the study subjects. The data was analyzed with the help of MS EXCEL.

Results: Among study population 53\% male, $47 \%$ female, $27 \%$ are in-service postgraduates. $52 \%$ from urban $46 \%$ rural \& $2 \%$ from tribal areas and $17 \%$ of the study population said that health care services are sufficient $83 \%$ disagreed, interestingly $56 \%$ are interested to work in rural areas.

Conclusion: About $56 \%$ of Postgraduates are interested to work in rural areas provided sufficient infrastructure is present.

Keywords:Attitude, infrastructure, living facilities, Post Graduate medical student, Rural Health Service

\section{Introduction}

According to 2011 census of India nearly two thirds i.e. $68.84 \%$ of population lives in rural areas. Even though India has made considerable progress in population health since independence especially in view of declined fertility and mortality in most states still India might not achieve health related Millennium Development Goals. Although a beginning has been made by the National Rural Health Mission, which is facing several constraints, such as insufficient deployment of human resources, especially in the health institutions located in the rural areas and lack of sufficient infrastructure. The lack of qualified medical professionals in rural areas has resulted in the majority of rural households receiving care from private providers, many of whom have little or no formal qualification to practice medicine. There is no doubt that the imbalance of doctors in rural and urban areas needs correction. Although 269 medical colleges in the country produce 30,922 doctors each year and there are 683,582 registered allopathic doctors in the country, only one in 10 doctors works in rural area. A fraction of rural health centres have the necessary physicians, surgeons and other personnel ${ }^{[1]}$.

Various salary and non-salary incentives play a part in why doctors typically choose not to serve in rural areas in India, even though government is offering salary incentives for rural health care workers which are not encouraging enough. Non-salary incentives are also important which cover a variety of dimensions such as living conditions, educational opportunities for employee's children and future career prospects. Of the 30,000 students who graduate from medical colleges each year, most tend to cluster in cities, where they have better living conditions, schools for their children, social recognition, higher incomes, promotion opportunities and great job satisfaction. In contrast, rural doctors fear that rural postings distance from their friends, families, professional colleagues and teachers, lead to physical and social isolation and lower their professional standing. Rural settings may lack appropriate mentors and students complain that they can neither acquire nor own technological skills in a village. Unsatisfactory working conditions, lack of adequate staff and equipment, and primitive living conditions add to their woes. In essence, doctors believe that not only does rural medical service fail to improve access to healthcare in these areas, it also requires personal sacrifice. And they ask why medical students are expected to make greater sacrifices than other professionals ${ }^{[1]}$

In view of the above mentioned salary and non-salary factors, most doctors now prefer to work in the comforts of urban hospital environments compared to rural health care setup, where facilities are far from 
optimum for practice of medicine as well as for living a decent life. Many doctors prefer to work in urban areas due to high incomes, better living conditions and better educational opportunities for their children.Identifying the attitudes of and intentions towards rural health care among current medical students especially postgraduate students who will become specialists and who will be handy in decreasingMaternal Mortality Rates and Infant Mortality Rates and tackling many other significant health related issues of rural India in the near future is very important to draw correct strategies and make good policies for the benefit of the rural population of India. With this background we conducted this study with objectives 1) To know the socio-demographic profile of study population 2) To study the attitude towards rural health service in postgraduate medical students.

\section{Methodology}

A cross sectional study was conducted in Andhra Medical Collage, Visakhapatnam, Andhra Pradesh In the month of November2012 Study was conducted among 100 randomly selected postgraduate medical students from a total of 540 of Andhra medical college with self-administered pre tested questionnaire.Informed consent was taken prior to the study. The data was analysed with the help of MS EXCEL.

\section{Results}

Among the study population $53 \%$ are male and $47 \%$ are female. Mean age of the study population is 30 years and $27 \%$ are in-service postgraduate students. $52 \%$ are from urban background, $46 \%$ from rural background and $2 \%$ with tribal background. According to modified BGPrasad's socioeconomic classification $42 \%$ belongs to upper high class, $41 \%$ to high class and $12 \%$ to upper middle class, $4 \%$ to lower middle class, only $1 \%$ belongs to lower class(Table no1)

TABLE No 1: Socio-demographic profile of study population

\begin{tabular}{|l|l|}
\hline & $(\mathrm{n}=100)$ \\
\hline Male & $53(53 \%)$ \\
\hline In-service PGs & $47(47 \%)$ \\
Non-service PGs & $27(27 \%)$ \\
\hline Urban background & $73(73 \%)$ \\
Rural background & $52(52 \%)$ \\
Tribal background & $46(46 \%)$ \\
\hline Economic classification(according to modified BG Prasad's classification) & $2(2 \%)$ \\
Upper high class & $42(42 \%)$ \\
High class & $41(41 \%)$ \\
Middle class & $12(12 \%)$ \\
Lower middle class & $4(4 \%)$ \\
Lower class & $1(1 \%)$ \\
\hline
\end{tabular}

$83 \%$ felt that present health care services in rural A.P are insufficient and $17 \%$ satisfied with them. $41 \%$ agree with the fact that need of specialist doctor services over MBBS doctors in rural areas while 59\% disagree. 56\% among study population expressed interest to work in rural areas. $17.88 \%$ wants work permanently and $82.12 \%$ wants to work temporarily at rural areas. $53 \%$ of study population felt that compulsory rural health residential ship for medical graduates and PGs is not necessary. 91\% agree with the fact that presently paid incentives are not sufficient and $72 \%$ feel that salary hike cannot compensate for lack of facilities. $85 \%$ feel that clinical infrastructure is not sufficient at ruralwork area(drugs,equipment,laboratories,ambulance etc.) and $80 \%$ say that there is not enough supporting staff for working. $91 \%$ are asking for mentoring staff need to guide them. $90 \%$ feel that job security (i.e. permanency of job, provision of incentives and pensions) can attract young doctors to rural health service and $94 \%$ are saying that present living facilities (i.e. housing, electricity, water, access to market, hygiene) for rural area serving doctors are insufficient.93\% feel that children of rural working doctors lag behind academically due to non-availability of good schooling and extra-curricular activities etc. $95 \%$ feel that there is a need for physical security and legal protection against political interference at work place in rural areas (Table no 2) 
TABLE No 2: Attitude towards Rural Health Service

\begin{tabular}{|c|c|}
\hline & $(n=100)$ \\
\hline $\begin{array}{l}\text { Present health services in rural Andhra Pradesh } \\
\text { Sufficient } \\
\text { insufficient }\end{array}$ & $\begin{array}{l}17(17 \%) \\
83(83 \%)\end{array}$ \\
\hline $\begin{array}{l}\text { Need of specialist doctor's services over MBBS doctors at rural areas } \\
\text { Yes } \\
\text { No }\end{array}$ & $\begin{array}{l}41(41 \%) \\
59(59 \%)\end{array}$ \\
\hline $\begin{array}{l}\text { PGs interested to work in rural areas } \\
\text { Interested } \\
\text { Not interested }\end{array}$ & $\begin{array}{l}56(56 \%) \\
\text { [permanently10(17.85\}\% } \\
\text { Temporarily } 46(82.15 \%)] \\
44(44 \%)\end{array}$ \\
\hline $\begin{array}{l}\text { Compulsory rural residential ship for PGs } \\
\text { Necessary } \\
\text { Not necessary }\end{array}$ & $\begin{array}{l}47(47 \%) \\
53(53 \%)\end{array}$ \\
\hline $\begin{array}{l}\text { Sufficiency of presently paid incentives for rural service } \\
\text { Sufficient } \\
\text { Insufficient }\end{array}$ & $\begin{array}{l}9(9 \%) \\
91(91 \%)\end{array}$ \\
\hline $\begin{array}{l}\text { Does salary hike can compensate for lack of facilities at rural working area } \\
\text { Yes } \\
\text { No }\end{array}$ & $\begin{array}{l}28(28 \%) \\
72(72 \%)\end{array}$ \\
\hline $\begin{array}{l}\text { Sufficiency of clinical infrastructure (i.e. drugs, equipment, laboratories, ambulance } \\
\text { etc.) } \\
\text { Sufficient } \\
\text { Insufficient }\end{array}$ & $\begin{array}{l}15(15 \%) \\
85(85 \%)\end{array}$ \\
\hline $\begin{array}{l}\text { Sufficiency of supporting staff(i.e. Helping hands) } \\
\text { Necessary } \\
\text { Not necessary }\end{array}$ & $\begin{array}{l}20(20 \%) \\
80(80 \%)\end{array}$ \\
\hline $\begin{array}{l}\text { Necessity of mentoring staff at rural areas } \\
\text { Necessary } \\
\text { Not necessary }\end{array}$ & $\begin{array}{l}91(91 \%) \\
9(9 \%)\end{array}$ \\
\hline $\begin{array}{l}\text { Can job security attract young doctors (i.e. permanency of job, provision of incentives } \\
\text { and pensions etc.)? } \\
\text { Yes } \\
\text { No }\end{array}$ & $\begin{array}{l}90(90 \%) \\
10(10 \%)\end{array}$ \\
\hline $\begin{array}{l}\text { Present living facilities for doctors at rural working area (housing, electricity, water, } \\
\text { access to market, hygiene etc.) } \\
\text { Sufficient } \\
\text { Insufficient }\end{array}$ & $\begin{array}{l}6(6 \%) \\
94(94 \%)\end{array}$ \\
\hline $\begin{array}{l}\text { Children's academic carrier will lag behind } \\
\text { Yes } \\
\text { No }\end{array}$ & $\begin{array}{l}7(7 \%) \\
93(93 \%)\end{array}$ \\
\hline
\end{tabular}

\section{Discussion}

In our study $83 \%$ of PGs think that presently available Health services in rural Andhra Pradesh are insufficient and $85 \%$ are of the opinion that there is an insufficient infrastructure provision by Gov't to deliver health care services which is reflected in a review article Issues of creating a new cadre of doctors for rural India $^{[2]}$.They found that the shortage is evidently more in the remote rural areas where there is need for services; and without health centres. The same article also mentioned that as per the available statistics $27 \%$ of the PHCs in Jharkhand have no road accessibility and $34.4 \%$ of the PHCs have no drinking water availability, $45 \%$ of the PHCs in Assam have no electricity supply and in Bihar 78\% of the PHCs have no phone connections, present study $94 \%$ of PGs think that living facilities in rural areas are deficient. In our study only $41 \%$ that there is a need of specialist doctor's services over MBBS doctors at rural areas, but there is a short fall of $8 \%$ doctors in PHCs, $65 \%$ for specialist at CHC,55.3\% for health workers(female)(2007) as per the view point article Kapil yadav et.al ${ }^{[3]}$, present study $46 \%$ of PGs have rural background and $56 \%$ of PGs are interested to work in rural areas among these only $17.88 \%$ are willing to work permanently in rural areas, which was reflected by observations mentioned in an editorial by SP Kalantri ${ }^{[1]}$ says that their experience in medical college established in semi-rural environment specifically to encourage community-based practice is that none of these strategies has been successful in encouraging medical students to stay and practice in rural areas. Students from rural backgrounds are as likely to practice in cities as are their urban raised peers.in our study $91 \%$ are of the opinion that presently paid incentives are insufficient and only hiking salaries won't attract doctors to serve in rural areas 
but also there is also a need to address about working conditions, children's education, living conditions and safety, which was reflected in a research study by Ramani et.al ${ }^{[4]}$.

\section{Conclusion}

Morethan $50 \%$ of postgraduate medical students are interested to work in rural areas of India. Once medical officerhave been posted, the onus should be on the government to make rural health services an attractive option in terms of pay, infrastructure, and availability of paramedical and support staff as well as career growth ${ }^{[5]}$.If government could provide basic infrastructure and living facilities and better working environment, we can expect good outcome in rural population health care sector. It is expected that a transparent, timely and merit-based competitive recruitment process to NRHM residency program would attract doctors to rural areas ${ }^{[6]}$.

\section{References}

[1]. Getting doctors to the villages; will compulsion work? Editorial by SP Kalantri, Indian journal of medical ethics vol 3 no4 oct- dec 2007

[2]. Issues of creating a new cadre of doctors for rural India Cherumanalil Jeeja International Journal of Medicine and Public Health Jan-Mar 2013 | Vol 3 | Issue 1

[3]. Revitalizing Rural Health Care Delivery: Can Rural Health Practitioners be the Answer? Kapil Yadav, Indian Journal of Community Medicine / Vol 34 / Issue 1 / January 2009

[4]. For more than love or money : Attitude of student and in-service health workers towards rural service in India Ramani et.al,Human Resources for Health 2013.

[5]. Attracting doctors to rural health services of India, Hemant Deepak Shewade,the national medical journal of India, vol 25,no 6, 2012 .

[6]. Involvement of young doctors in the rural health services of India, editorial, Indian journal of public health, vol 56, issue 1,janmarch 2012 . 